\title{
Emolehmien maidon koostumus alkulaktaatiokaudella
}

\author{
Heta Sillanpää, Mirja Riipinen \\ Biotalousinstituutti, Jyväskylän ammattikorkeakoulu, Tuumalantie 17, 43130 Tarvaala \\ heta.sillanpaa@lantmannenagro.fi,mirja.riipinen@jamk.fi
}

\section{TIIVISTELMÄ}

Suomessa emolehmien maidon koostumusta on tutkittu vähänlaisesti. Kun vuonna 2017 julkaistiin uudet ruokintasuositukset emolehmille, katsottiin emolehmien maidon koostumuksen tutkiminen ajankohtaiseksi. Tutkimukseen osallistui kolme tilaa Keski-Suomesta ja Savosta. Tiloilla kasvatettiin aberdeen angus-, charolais-, ja hereford-rotuisia nautoja. Tutkimuksen tarkoituksena oli selvittää emolehmien maidon koostumusta alkulaktaatiokaudella. Tutkimukseen osallistuneiden tilojen lehmät olivat kevätpoikivia, joten aineistonkeruu suoritettiin kevään ja kesän 2018 aikana. Tiloilta kerättiin maitonäytteiden lisäksi perustiedot karjasta sekä eläinten ruokinnasta. Yksityiskohtaisia ruokintatietoja tai ruokintasuunnitelmia ei saatu. Maitonäytteet otettiin tiloilla itsenäisesti ohjeiden mukaisesti ja saadut näytteet kuljetettiin Valion Seinäjoen aluelaboratorioon, jossa maidosta analysoitiin rasva-, valkuais-, laktoosi-, kuiva-aine- ja ureapitoisuus sekä somaattiset solut.

Maitonäytteitä saatiin 77 kappaletta, joista 23 oli angus-emoilta. Charolais- ja hereford-emoilta näytteitä saatiin kumpaisenkin rodun edustajilta 27. Tuloksia verrattiin aikaisempiin tutkimuksiin, joiden tuloksissa huomattiin samankaltaisuuksia. Tutkimusemojen maidon valkuaispitoisuuden huomattiin olevan hieman korkeampi (3.76\% $3.95 \%$ ) kuin aikaisemmissa näitä rotuja koskeneissa tutkimuksissa (2.90 \%-3.50\%). Vastaavasti maidon laktoosipitoisuus oli matalampi (3.98\%-4.40\%) verrattuna aikaisempiin tutkimuksiin $(4.65 \%-5.50 \%)$. Maidon ureapitoisuudet olivat tässä tutkimuksessa matalalla tasolla etenkin angus- ja hereford-emoilla. Tutkimuksessa ei ollut mahdollisuutta mitata emojen maitotuotosta vaan maitonäytteet on lypsetty käsin. Tämä aiheutti arveluttavia tuloksia etenkin maidon rasvapitoisuuden osalta.

Asiasanat: emolehmien ruokinta, emolehmien maidon koostumus

\section{Johdanto}

Vuonna 2016 Suomessa oli 2157 emolehmätilaa. Samana vuonna emolehmien määrä Suomessa oli lähes 59000 (Luke 2016). Emolehmätuotannossa tavoitteena on tuottaa laadukkaita ja elinvoimaisia vasikoita, joten ravitseva maito on luonnollisesti edellytys vasikan alkuvaiheen hyvälle kasvulle. Emolehmien maidon koostumusta on tutkittu vähänlaisesti tuotantosuunnan luonteesta johtuen, sillä harvemmin emoja lypsetään ihmisen toimesta. Etenkin Suomalaista tutkimustietoa aiheesta oli saatavilla vain vähän. Tästä syystä lisätutkimukselle katsottiin olevan tarvetta, etenkin kun emolehmille julkaistiin uudet ruokintasuositukset vuonna 2017. Tässä tutkimuksessa haluttiin selvittää emolehmien maidon koostumusta alkulaktaatiokaudella. Tavoitteena oli saada lisää tietoa emolehmien maidon koostumuksesta ja pitosuuksiin vaikuttavista seikoista. Tutkimuksessa vertailtiin myös rotujen välisiä pitoisuuksien eroavaisuuksia laktaatiokauden edetessä.

Tutkimus toteutettiin Jyväskylän Ammattikorkeakoulun biotalousinstituutissa Tarvaalassa opinnäytetyönä. Työn toimeksiantaja oli Menestyvä keskisuomalainen nautakarjatila-hanke, eli MEKA. Meka -hanke tarjosi koulutuksia alkutuotannon toimijoille, pääpainonaan maidon- ja naudanlihantuotanto sekä yrittäjien hyvinvointi (Menestyvä keskisuomalainen nautakarjatila n.d.). 


\section{Materiaalit ja menetelmät}

Tutkimukseen osallistui kolme emolehmätilaa, joilla oli aberdeen angus-, hereford- ja charolaisrotuista karjaa. Tutkimusaineisto kerättiin tiloilla kevään ja alkukesän 2018 aikana. Kultakin emolta kerättiin 3-5 maitonäytettä niin, että ensimmäinen näyte otettiin viikon kuluttua poikimisesta ja tämän jälkeen näytteenotto tapahtui kahden viikon välein.

Tilalliset ottivat maitonäytteet itsenäisesti valitsemiltaan koe-eläimiltä ohjeiden mukaisesti. Maitonäyte lypsettiin käsin kahden desilitran astiaan, josta se kaadettiin sekoittamisen jälkeen näytepikariin. Lisäksi näytteenottotilanteessa täytettiin kaksi lomaketta, joista toinen käsitteli näytteenottotilannetta ja toinen täytettiin Valion laboratoriota varten lähetettävän maitonäytteen mukaan. Tilalliset toimittivat näytteet sovituille maitotiloille, joilta näytteet kuljetettiin paikallisten maidonkuljetusyritysten mukana Valion Seinäjoen laboratoriolle. Maidosta analysoitiin rasva-, valkuais-, laktoosi-, kuiva-aine- ja ureapitoisuus sekä somaattiset solut. Maitonäytteiden lisäksi tiloilta kerättiin lisäksi yleistiedot karjasta ja sen ruokinnasta. Saatu aineisto koottiin ja analysoitiin käyttämällä Microsoft Excel taulukkolaskentaohjelmaa. Saatuja tuloksia vertailtiin aikaisempien samankaltaisten tutkimusten tuloksiin.

\section{Tulokset}

Maidon koostumus käyttäytyi laktaatiokauden edetessä samankaltaisesti kullakin eri rodulla. Ensimmäisellä näytteenottokerralla, viikon kuluttua poikimisesta kaikilla roduilla maidon valkuaispitoisuus oli huipussaan ja laktoosipitoisuus alhaisimmillaan. Angus- ja charolais-emoilla myös maidon rasvapitoisuus oli korkein ensimmäisen viikon jälkeen poikimisesta. Herefordit olivat poikkeus, sillä niiden korkein rasvapitoisuus mitattiin seitsemän viikon kuluttua poikimisesta. Tässä tutkimuksessa maitonäytteet eivät kuitenkaan edustaneet emolehmien kokonaismaitomäärää, joten etenkin rasvapitoisuuden osalta tulos voi olla virheellinen.

Angus-emojen huomattiin lypsäneen keskimäärin valkuais-ja rasvapitoisinta maitoa. Samalla niiden maidon laktoosipitoisuus oli pienin verrattuna kahteen muuhun rotuun. Myös aikaisemmissa tutkimuksissa on huomattu angus-emojen maidon alhaisempi laktoosipitoisuus, mutta tällöin myös niiden maidon rasva- ja valkuaispitoisuudet ovat olleet matalampia kuin tässä tutkimuksessa. Angus emoilla näytteiden keskimääräinen maidon valkuaispitoisuus oli $3.95 \%$, rasvapitoisuus $4.10 \%$ ja laktoosipitoisuus 3.98 \%. Urean määrä oli keskimäärin $11.02 \mathrm{mg} / 100 \mathrm{ml}$ ja kuiva-ainetta näytteissä oli keskimäärin $13.03 \%$ (Taulukko 1.)

Taulukko 1. Maidon keskimääräiset pitoisuudet angus-emoilla

\begin{tabular}{lccccc}
\hline & \multicolumn{5}{c}{ Angus n 23 } \\
\cline { 2 - 6 } & $\begin{array}{c}\text { Valkuainen } \\
\%\end{array}$ & Rasva \% & Laktoosi \% & $\begin{array}{c}\text { Urea mg/ } \\
100 \mathrm{ml}\end{array}$ & Kuiva-aine \% \\
\hline Keskiarvo & 3.95 & 4.1 & 3.98 & 11.02 & 13.03 \\
Minimi & 3.25 & 0.81 & 2.2 & 0.1 & 9.16 \\
Maksimi & 5.91 & 9.61 & 4.58 & 21.2 & 18.55 \\
Keskihajonta & 0.71 & 1.98 & 0.66 & 5.27 & 2.06 \\
\hline
\end{tabular}

Charolais -emoilla näytteiden keskimääräinen maidon valkuaispitoisuus oli $3.76 \%$, rasvapitoisuus $3.44 \%$ ja laktoosipitoisuus $4.36 \%$. Keskimäärin ureapitoisuus oli $23.71 \%$ ja kuiva-ainepitoisuus $12.69 \%$ (Taulukko 2). 
Taulukko 2. Maidon keskimääräiset pitoisuudet charolais-emoilla

\begin{tabular}{lccccc}
\hline & \multicolumn{5}{c}{ Charolais n 27 } \\
\cline { 2 - 6 } & $\begin{array}{c}\text { Valkuainen } \\
\%\end{array}$ & Rasva \% & Laktoosi \% & $\begin{array}{c}\text { Urea mg/ } \\
100 \mathrm{ml}\end{array}$ & Kuiva-aine \% \\
\hline Keskiarvo & 3.76 & 3.44 & 4.36 & 23.71 & 12.69 \\
Minimi & 3.27 & 0.46 & 2.6 & 13 & 9.64 \\
Maksimi & 5.32 & 8.69 & 5.01 & 35.9 & 17.83 \\
Keskihajonta & 0.41 & 2 & 0.5 & 6.01 & 1.99 \\
\hline
\end{tabular}

Hereford -emoilla näytteiden keskimääräinen maidon valkuaispitoisuus oli 3.79 \%, rasvapitoisuus 3.99 $\%$ ja laktoosipitoisuus $4.40 \%$. Ureaa oli keskimäärin $11.64 \mathrm{mg} / 100 \mathrm{ml}$ ja maidon kuiva-aine oli keskimäärin $13.37 \%$ (Taulukko 3).

Taulukko 3. Maidon keskimääräiset pitoisuudet hereford-emoilla

\begin{tabular}{lccccc}
\hline & \multicolumn{5}{c}{ Hereford n 27 } \\
\cline { 2 - 6 } & $\begin{array}{c}\text { Valkuainen } \\
\%\end{array}$ & Rasva \% & Laktoosi \% & $\begin{array}{c}\text { Urea mg/ } \\
100 \mathrm{ml}\end{array}$ & Kuiva-aine \% \\
\hline Keskiarvo & 3.79 & 3.99 & 4.4 & 11.64 & 13.37 \\
Minimi & 3.25 & 1.05 & 3.27 & 2.7 & 10.52 \\
Maksimi & 4.65 & 10.24 & 4.93 & 23.6 & 19.5 \\
Keskihajonta & 0.38 & 2.18 & 0.36 & 4.32 & 2.03 \\
\hline
\end{tabular}

\section{Johtopäätökset}

Tutkimustuloksia tarkastellessa huomattiin, että kaikilla kolmella rodulla maidon valkuaispitoisuus oli korkeampi (3.76 - 3.95 \%) kuin rotuja koskeneissa verrokkitutkimuksissa (ks. Taulukko 4), joissa se oli 2.90 - 3.50 prosenttia. Emolehmien valkuaisruokintasuosituksissa maidon valkuaispitoisuutena käytetään 31 grammaa kilossa, mikä on hivenen alakanttiin tämän tutkimuksen tuloksiin verrattuna. Maidon laktoosipitoisuus, 3.98 - 4.40 prosenttia, oli alhaisempi kuin aikaisemmissa tutkimuksissa, joissa se on ollut $4.65-5.50$ prosenttia. Maidon rasvapitoisuus, $3.44-4.10$ prosenttia, oli kullakin rodulla hyvin samankaltainen verrattuna aikaisempiin tutkimuksiin.

Taulukko 4. Verrokkitutkimukset

\begin{tabular}{lcccc}
\hline Rotu & $\begin{array}{c}\text { Maidon } \\
\text { valkuaispitoisuus } \\
(\%)\end{array}$ & $\begin{array}{c}\text { Maidon } \\
\text { rasvapitoisuus } \\
(\%)\end{array}$ & $\begin{array}{c}\text { Maidon } \\
\text { laktoosipitoisuus } \\
(\%)\end{array}$ & Lähde \\
\hline Angus & 3.32 & 4.1 & 4.7 & Beal ym. 1990 \\
Angus & 2.9 & 3.21 & 4.65 & Rodrigues ym. 2014 \\
Charolais & 3.5 & 3.4 & 5.2 & Velazquez 2000 \\
Hereford & 3.39 & 4.06 & 5.01 & Manninen ym. 2006 \\
Hereford & 3.5 & 4.9 & 5.5 & Velazquez 2000 \\
Hereford & 3.3 & 6.3 & 5 & Velazquez 2000 \\
\hline
\end{tabular}

Yhdeltäkään tilalta ei saatu yksityiskohtaisia ruokintasuunnitelmia, vaan kukin tila ilmoitti ruokinnan suurpiirteisesti. Angus-emoilla ruokinta perustui pitkälti esikuivattuun säilörehuun. Charolais-emot 
saivat säilörehun lisäksi kauran ja vehnän seosta, rypsiä sekä kivennäis-ja vitamiinivalmisteita. Herefordien ruokinta perustui kuivaheinän kaltaiseen, vanhana korjattuun nurmirehuun.

Vaikkakin mittaustietojen saanti oli vaikeaa, voidaan näiden tulosten valossa todeta, että ruokinta heijastuu myös emolehmillä maidon koostumukseen samankaltaisesti kuin lypsylehmilläkin. Tässä tutkimuksessa asia tuli ilmi erityisesti maidon ureapitoisuudessa (Taulukko 5), jonka normaalitasona pidetään yleisesti $19-29 \mathrm{mg} / 100 \mathrm{ml}$. Maidon ureapitoisuuksien huomattiin olevan tässä tutkimuksessa matala etenkin angus- ja hereford-emoilla, mikä johtunee emojen ruokinnan yksinkertaisuudesta. Alhainen urea kertoo, että pötsissä on hajoavaa valkuaista suhteellisesti vähän verrattuna energian saantiin.

Taulukko 5. Maidon ureapitoisuudet

\begin{tabular}{lccc}
\hline & Angus & Charolais & Hereford \\
\hline Keskiarvo & 11.02 & 23.71 & 11.64 \\
Minimi & 0.1 & 13 & 2.7 \\
Maksimi & 21.2 & 35.9 & 23.6 \\
\hline
\end{tabular}

\section{Kirjallisuusluettelo}

Beal, W.E., Notter, D.R. \& Akers, R.M. 1990. Techniques for estimation of milk yield in beef cows and relationships of milk yield to calf weight gain and postpartum reproduction. Blacksburg: Virginia Polytechnic Institute and State University. Journal of Animal Science 68:937-943. https://doi.org/10.2527/1990.684937x

Luke 2016. Tilastotietokanta: kotieläinten lukumäärä. http://statdb.luke.fi/PXWeb/pxweb/fi/LUKE/LUKE_ 02\%20Maatalous_ 04\%20Tuotanto_ 12\%20Kotielainten \%20lukumaara/09_Kotielainten_lukumaara.px/table/tableViewLayout1/?rxid=d58b5334-7ba6-4467-bfbb488f63986d98

Manninen M., Sormunen-Cristian, R., Jauhiainen, L., Sankari, S. \& Soveri, T. 2006. Emolehmien harvennetun ruokinnan tuotos- ja hyvinvointivaikutukset. Julkaisussa: Laatulihaa tehokkaalla emolehmätuotannolla. Heikkilä, A.-M. (toim.). MTT:n selvityksiä 113. Helsinki: MTT Taloustutkimus.

Menestyvä keskisuomalainen nautakarjatila. N.d. https://www.aitomaaseutu.fi/hankkeet/menestyvakeskisuomalainen-nautakarjatila-meka

Rodrigues, P.F., Menezes, L.M., Azambuja, R.C.C., Suñé, R.W., Barbosa Silveira, I.D. \& Cardoso, F.F. 2014. Milk yield and composition from Angus and Angus-cross beef cows raised in southern Brazil. Journal of Animal Science 92. https://doi.org/10.2527/jas.2013-7055

Velazquez, M. 2000. Udder health and milk composition, with special reference to beef cows - A literature review. 